\title{
Ammonia Losses from Outdoor Pig Fattening at Two Swedish Organic Farms
}

\author{
E. Salomon ${ }^{*}, 1$, L. Rodhe ${ }^{1}$, J. Malgeryd ${ }^{2}$, K. Lindgren ${ }^{1}$ and C. Lindah $1^{1}$ \\ ${ }^{I}$ Swedish Institute of Agricultural and Environmental Engineering, P.O. Box 7033, SE-750 07 Uppsala, Sweden \\ ${ }^{2}$ Swedish Board of Agriculture, SE-581 86 Linköping, Sweden
}

\begin{abstract}
Ammonia $\left(\mathrm{NH}_{3}\right)$ emissions originate predominantly from manure. In outdoor pig production, excretory behaviour creates nitrogen $(\mathrm{N})$ point loads. This study examined ammonia losses from pigs on grassland at two farms by calculating $\mathrm{N}$ field balances per pen and sub-areas preferred (P) and not preferred (NP) for excretion. Spatial variation in ammonia losses was measured with an equilibrium concentration method in one pen per farm during two years at the end of the fattening period. Cumulative ammonia losses during a fattening period were measured using a micrometeorological mass balance method. P sub-areas had 10- to 100-fold higher amounts of excreted N than NP sub-areas. Ammonia losses were higher from P sub-areas (0.056-1.843 $\left.\mathrm{g} \mathrm{NH}_{3} \mathrm{ha}^{-1} \mathrm{hr}^{-1}\right)$ than from NP sub-areas $\left(0.001-0.332 \mathrm{~g} \mathrm{NH}_{3} \mathrm{ha}^{-1} \mathrm{hr}^{-1}\right)$. Ammonia losses from NP sub-areas varied more widely. Cumulative $\mathrm{NH}_{3}$ losses were $28 \mathrm{~kg} \mathrm{pen}^{-1}$. Gross $\mathrm{NH}_{3}$ losses were $0.66 \mathrm{~kg} \mathrm{~N} \mathrm{pig}^{-1}$, representing $14 \%$ of excreted $\mathrm{N}$.
\end{abstract}

Keywords: Ammonia losses, fattening pigs, grasslands, organic, outdoors.

\section{INTRODUCTION}

In Europe, ammonia $\left(\mathrm{NH}_{3}\right)$ emissions from livestock production are one of the most important factors contributing to eutrophication and acidification of land and water [1]. In Sweden, $85 \%$ of ammonia emissions to the atmosphere originate from agriculture, predominantly from management of animal manure. A minor proportion of total ammonia emissions (8\%) originates from grazing livestock [2]. Almost all fattening pigs in Sweden are housed indoors and the slurry management system dominates [3].

Outdoor pig production is gaining interest as it has benefits in terms of animal welfare and low costs of buildings and equipment $[4,5]$. Swedish regulations on organic pig production currently require pigs to have access to grazing areas during the growing season [6]. In Sweden, about $1 \%$ of fattening pigs are organically reared $[7,3]$. There are few studies of $\mathrm{N}$ losses from pigs on grassland, but $\mathrm{N}$ can be expected to be released through $\mathrm{NH}_{3}$ volatilisation, denitrification and nitrate leaching [8-10]. Pig rooting behaviour damages the grass sward and increases the potential for $\mathrm{N}$ leaching [11]. However, the effect of outdoor pigs on ammonia losses has been less investigated.

In Danish studies, spatial variations in ammonia emissions were reported within pens with lactating sows $[9,10]$. This can depend on the excretory behaviour of pigs, which creates plant nutrient hot-spots in outdoor areas $[5,12,13]$. In one of the Danish studies [9], there was a correlation between increasing ammonia losses and increasing amounts of feed given to sows, resulting in increased amounts of

*Address correspondence to this author at the Swedish Institute of Agricultural and Environmental Engineering, P.O. Box 7033, SE-750 07 Uppsala, Sweden; Tel: +46 183033 61; Fax: +46 183009 56;

E-mail: eva.salomon@jti.se excreted $\mathrm{N}$. In general, increasing the amounts of $\mathrm{N}$ applied results in a proportionate increase in ammonia emissions [14].

The objectives of the present study were to: (1) Measure the spatial variation in momentary losses of ammonia from sub-areas preferred and not preferred for excretion within outdoor pens at two organic farms; and (2) measure cumulative ammonia losses during the fattening period at a farm with huts and feeding in the pen.

\section{MATERIALS AND METHODOLOGY}

\subsection{Sites and Outdoor Management}

One of the farms used huts and fed the pigs in outdoor pens. The hut farm was a commercial pig farm with a production rate of about 700 fattening pigs per year and 150 ha of arable land, located in south-central Sweden $\left(59^{\circ} 30^{\prime} \mathrm{N}\right.$, $\left.17^{\circ} 20^{\prime} \mathrm{E}\right)$. The farm had its own sows and bred its own piglets. The other farm fed the pigs indoors in a barn all the year around. This farm was a commercial pig farm with a production rate of about 800 fattening pigs per year and 80 ha of arable land, located in southern Sweden ( $\left.58^{\circ} 20^{\prime} \mathrm{N} ; 14^{\circ} 10^{\prime} \mathrm{E}\right)$. The farm bought in piglets. Both farms had been organically managed for four years at the start of this study.

At the hut farm, the pens for pigs were included in a fouryear crop rotation. Each herd of about 40 pigs utilised a clover/grass ley not previously affected by pigs and the rectangular pen was surrounded by electric fences. Within a pen, the pigs had access to wallows, huts for shelter and feeding and drinking places, Fig. (1). The barn farm had a barn in close proximity to arable land where the pens for pigs were included in a two-year crop rotation. A small part of the arable land close to the barn was used for pigs each year. In the 


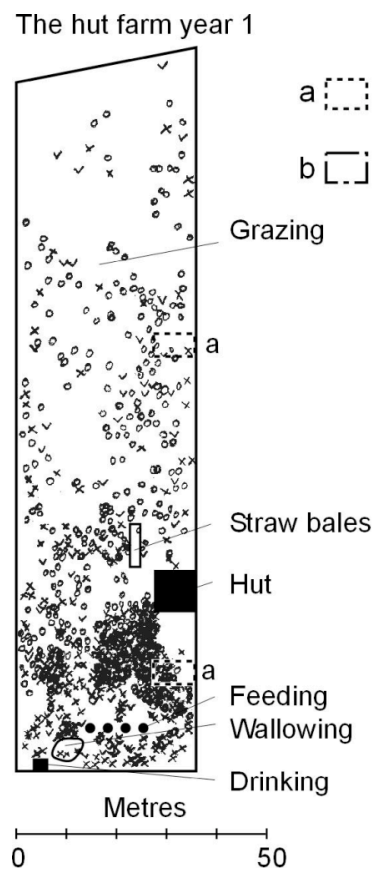

The hut farm year 2

The equilibrium concentration method

The micrometeorological mass balance method

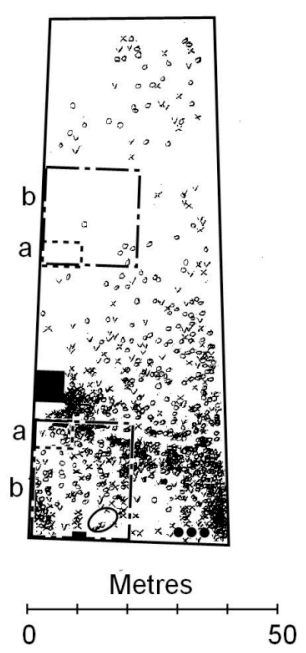

The barn farm year 2

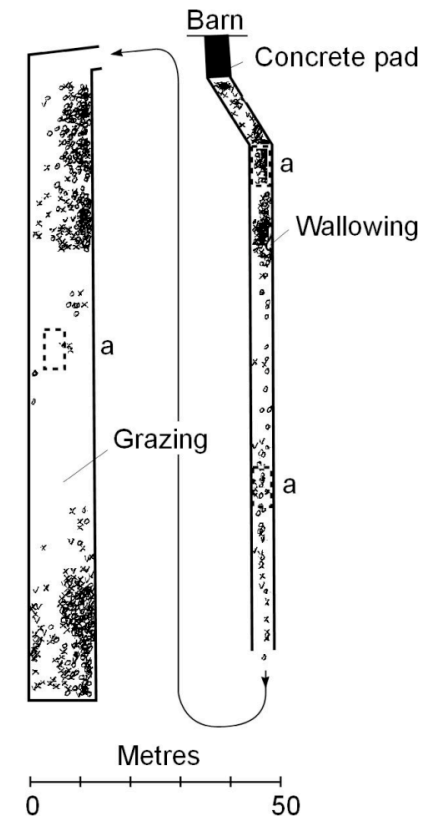

Fig. (1). Maps of defecation and urination in pens at the hut farm and barn farm. $o=$ manure, $x=$ urine from male pigs, $v=$ urine from female pigs. The rectangular areas in pens represent the areas used for measuring ammonia losses.

Table 1. Pig Density, Fattening Period, Average $\mathbf{N}$ in Feed, and Areas/Sub-Area in Pens where Ammonia Losses were Measured

\begin{tabular}{|c|c|c|c|}
\hline Farm & $\underline{\text { Hut farm }}$ & $n$ farm & \\
\hline Year & 1 & 2 & \\
\hline Fattening pigs ha ${ }^{-1}$ & 75 & 90 & 96 \\
\hline Fattening period, days & 153 & 152 & 128 \\
\hline Average $\mathrm{N}$ in feed, $\mathrm{kg} \mathrm{pig}^{-1}$ day $^{-1}$ & 5.4 & 7.7 & 6.0 \\
\hline Total pen area, $\mathrm{m}^{2}$ & 4540 & 3899 & 3333 \\
\hline P sub-areas, $\mathrm{m}^{2}$ & 1054 & 1119 & 201 \\
\hline 'NP sub-areas, $\mathrm{m}^{2}$ & 3486 & 2781 & 3102 \\
\hline
\end{tabular}

${ }^{\mathrm{a}} \mathrm{P}$ sub-area $=$ area preferred by pigs for excretion; NP sub-area $=$ area where the pigs did not prefer to excrete.

barn, each herd of about 40 pigs had a box including feeding equipment and a lying area with straw litter. Outside the barn, a concrete pad led to a long and narrow transfer area with the wallowing area and beyond that the clover/grass ley, Fig. (1). Additional production data are presented in Table 1.

In a parallel study [15], behavioural studies were conducted in pens in order to identify sub-areas corresponding to pig activity at both farms, including those pens where ammonia losses were measured. The spatial variation in frequency of excretion within the pen was included in these behavioural studies, allowing sub-areas within the pen preferred and not preferred for excretion to be defined. In all pens at the hut farm, the sub-area preferred for excretion was located between the hut and the feeding area, while in all pens at the barn farm it was located just outside the barn on the concrete pad and around the wallowing area. In all pens at both farms, the sub-area where the pigs preferred not to excrete was within the grazing area. Maps of defecation and urination for pens in this study are shown in Fig. (1).

At the hut farm, the arable land included in this study was a clay soil [16] with mean total $\mathrm{N}$ comprising $0.21 \%$ of DM content, mean total C $1.57 \%$ of DM content and topsoil $\mathrm{pH}(0-30 \mathrm{~cm}$ depth) 6.7. The arable land at the barn farm was a sandy loam [16] with mean total $\mathrm{N}$ comprising $0.15 \%$ of DM content, mean total $\mathrm{C} 2.00 \%$ of DM content and $\mathrm{pH} 6.2$. Sampling and analysis of the pens are described in a parallel study [17].

\subsection{Experimental Set-Up}

Ammonia losses were measured at the two farms in one outdoor pen per farm and year. Ammonia losses were measured within pens in sub-areas where the pigs preferred to excrete and did not prefer to excrete. During two years am- 
monia losses were measured at the end of the fattening period to reflect the time when the pigs were heaviest and had highest feed consumption. In year 1 , the pig herds included in the study were outdoors from August to November on both farms, while in year 2 the pig herds studied were outdoors from June to September. Measurements of ammonia losses in year 1 at the barn farm were affected by heavy rain and therefore this treatment was excluded from the results. In order to study ammonia losses during the whole fattening period, measurements of cumulative ammonia losses were conducted in year 2 from the same pen at the hut farm where measurements were made of ammonia losses at the end of the fattening period. A nitrogen field balance was calculated for each pen on the basis of measured primary data.

\subsubsection{Measurements of Weather Conditions}

At the hut farm during the study in year 1, the total precipitation was $50 \mathrm{~mm}$, with zero precipitation in August, and the temperature ranged between 2.8 and $22.0{ }^{\circ} \mathrm{C}$. In year 2 the total precipitation was $236 \mathrm{~mm}$ and the mean temperature 3.3 to $16.2^{\circ} \mathrm{C}$. At the barn farm during the study in year 2 , the total precipitation was $410 \mathrm{~mm}$ and the temperature 10.3 to $17.6{ }^{\circ} \mathrm{C}$. Air temperature in the outdoor fattening periods was recorded every hour by a StowAway ${ }^{\circledR}$ XTI temperature log model (Onset Computer Corporation, USA). Precipitation data were based on documentation from a nearby weather station [18]. At both sites, the study period in year 1 was dryer and warmer than the 30 -year average [19], while year 2 was wetter and warmer.

During measurements of ammonia losses, the air temperature at $1.5 \mathrm{~m}$ height, soil surface temperature and wind speed at $2 \mathrm{~m}$ height were measured with a Vicon WS 801 weather station (Vicon Ltd., Ipswich, U.K.).

\subsection{Nitrogen Field Balance}

Nitrogen field balances for each pen for the whole fattening period were calculated from Eqn. (1) and were assumed to be the total amount of $\mathrm{N}$ excreted [20].

$\mathrm{N}_{\text {field balance }}=\mathrm{N}_{\text {input }}-\mathrm{N}_{\text {output }}=\left(\mathrm{N}_{\text {sows in }}+\mathrm{N}_{\text {piglets in }}+\mathrm{N}_{\text {feed }}\right)-$ $\left(\mathrm{N}_{\text {sows out }}+\mathrm{N}_{\text {fattened pigs out }}+\mathrm{N}_{\text {excretion in barn }}\right)$

Inputs and outputs of $\mathrm{N}$ in the form of pigs were calculated by multiplying measured pig weight by mean $\mathrm{N}$ content in pig bodies [21]. The $\mathrm{N}$ concentration in feed components used at the two farms was taken from a parallel study [17] and multiplied by measured amounts of feed consumed by each pig group in this study.

At the barn farm, the amount of $\mathrm{N}$ in the indoor litter bed at the end of the fattening period was determined from the weight and the $\mathrm{N}$ concentration analysed in the bed in a parallel study [22]. The total amount of $\mathrm{N}$ in the litter bed for the pig group in year 2 corresponded to $0.5 \mathrm{~kg} \mathrm{pig}^{-1}$.

In a parallel study [15], the number of defecations and urinations in sub-areas within each pen were used to calculate the relative proportion of excretions per sub-area in relation to the total number of defecations and urinations per 10 pigs and $10 \mathrm{~m}^{2}$. The relative proportions of excretion in subareas preferred and not preferred for excretion for each pen were used in this study to calculate amounts of $\mathrm{N}$ excreted per sub-area, based on the $\mathrm{N}$ field balance for each pen.

\subsection{Ammonia Measurements}

\subsubsection{Momentary Spatial Losses of Ammonia}

Spatial variation in ammonia losses within the pen was measured momentarily in both systems with an equilibrium concentration method $[23,14]$. The method can be considered reliable for measuring ammonia concentrations higher than 1 ppm in air [23]. The measurements were conducted at the end of the fattening period. The areas used for measuring ammonia losses are marked in Fig. (1). The method is suitable for measuring losses from small areas [24] and in situations where turbulent wind conditions could be expected due to nearby buildings.

Both in sub-areas preferred and not preferred for excretion, three chambers and one ambient sampler unit were randomly placed in an area representing $60 \mathrm{~m}^{2}$, Fig. (2). The ammonia losses were measured in three periods during three days in year 1 and in two periods during two days in year 2 (Table 2). For the time between two measuring periods, the ammonia losses were interpolated according to [25]. The equipment was surrounded by electric fencing during the measuring occasion to keep the pigs from interfering with measurements. In order to determine the appropriate exposure times for the samplers, the ammonia concentrations in the ventilated chambers were measured at the start of the sampler exposure with a Kitagawa gas detector tube system (Komyo Rikagaku Kogyo K.K.). Using data from [26], the minimum and maximum exposure time of the samplers were set from the concentration value measured with the detector tube.

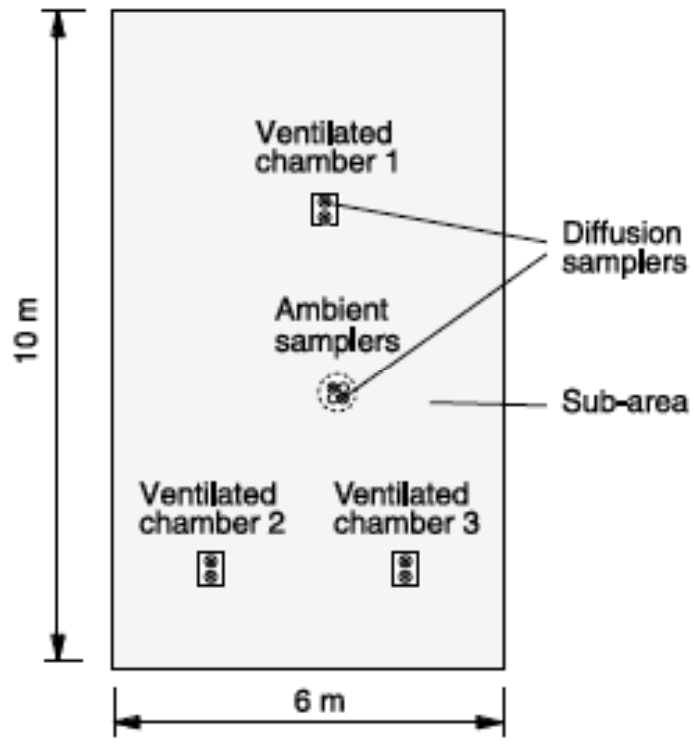

Fig. (2). Sampling arrangement, with three ventilated chambers and one holder for ambient samplers in each sub-area, for ammonia measurements with the equilibrium concentration method.

\subsubsection{Cumulative Ammonia Losses}

In order to estimate the ammonia losses during a whole fattening period for outdoor pigs, additional measurements were made with a micrometeorological mass balance method described by [27] and applied by [28]. It was used at the hut farm in year 2 , as this pen was situated on an open field and not close to high buildings giving rise to turbulent winds. The areas used for measuring ammonia losses are marked in 
Table 2. Measuring Conditions for the Equilibrium Concentration Method at the End of the Fattening Period at the hut Farm (HF) and the Barn Farm (BF) in Years 1 and 2

\begin{tabular}{|c|c|c|c|c|c|}
\hline \multirow{2}{*}{$\begin{array}{l}\text { Farm } \\
\text { \& year }\end{array}$} & \multirow[b]{2}{*}{ Measuring period } & \multicolumn{2}{|l|}{ a) } & \multicolumn{2}{|c|}{ Average temp. $\left(C^{\circ}\right)$} \\
\hline & & Pigs pen ${ }^{-1}$ & Date of slaughter & Air & Soil surface \\
\hline HF1 & 28 Oct., 3 hrs & 27 & 20 Nov. & 3.6 & 4.1. \\
\hline HF1 & 29 Oct., 5 hrs & 27 & 20 Nov. & 4.4 & 2.3 \\
\hline HF1 & 31 Oct., 4 hrs & 27 & 20 Nov. & 2.7 & 0.5 \\
\hline HF2 & 25 Sept., 24 hrs & 21 & 31 Sept. & 14.0 & 13.8 \\
\hline HF2 & 26 Sept., 5 hrs & 21 & 31 Sept. & 15.2 & 18. \\
\hline BF1 H & Excluded due to heavy rain & & - & - & \\
\hline $\mathrm{BF} 2$ & 25 Aug., 2 hrs & 25 & 31 Aug. & 19.1 & 22.5 \\
\hline $\mathrm{BF} 2$ & 26 Aug., 4 hrs & 25 & 31 Aug. & 16.9 & 18.1 \\
\hline
\end{tabular}

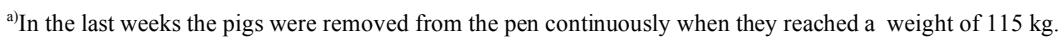

Table 3. Conditions where Ferm Tubes were Used for Measuring the Micrometeorological Mass Balance During the Fattening Period at the hut Farm in Year 2

\begin{tabular}{lrlllr}
\hline & \multicolumn{5}{c}{ Starting date of each measuring period } \\
\cline { 2 - 6 } Conditions & 5 June & 11 July & 13 Aug. & 17 Sept. & 25 Sept. \\
\hline Hours of exposure & 192 & 166 & 167 & 193 & 193 \\
Average air temp. $\left({ }^{\circ} \mathrm{C}\right)$ & 16.3 & 20.9 & 17.0 & 13.1 & 8.4 \\
Total precipitation $(\mathrm{mm})$ & 32 & 6 & 49 & 20 & 10 \\
No. of pigs in pen & 35 & 35 & 35 & 31 & 21
\end{tabular}

Fig. (1). Measurements were made both in sub-areas preferred and not preferred for excretion. With the method, it was possible to measure ammonia losses from large plots (20 $\mathrm{m}$ by $20 \mathrm{~m}$ ) and also to expose the samplers during relatively long periods. The method therefore summarises the ammonia losses over both surface and time of exposure. Table $\mathbf{3}$ shows the measuring periods and conditions in the exposure periods. The losses between measurements were interpolated.

Four masts with passive flux samplers were used for each sub-area, Fig. (3). Electric fencing surrounded the masts during the measuring periods. At the start of each measuring period, duplicate passive flux samplers were attached at four different heights on each mast $(0.46,1.84,4.60$ and $8.0 \mathrm{~m}$ above the ground surface). The sampler at each mast and height consists of 2 glass tubes, each with a length of $10 \mathrm{~cm}$ and an internal diameter of $0.7 \mathrm{~cm}$. The two glass tubes are connected in series, with one end fitted with a thin stainless steel disc having a $1 \mathrm{~mm}$ hole in the centre. Tubes and stainless steel discs were manufactured by Mikrolab Aarhus A/S, Axel Kiers Vej 34, DK-8270 Hoejbjerg, Denmark. The inner surface of each glass tube is coated with $1.36 \mathrm{mg}$ oxalic acid. At the end of the exposures period the flux samplers were taken down from the mass and closed with plastic caps. In the laboratory, $0.003 \mathrm{~L}$ deionised water was added to each glass tube in order to dissolve the oxalic acid coating. Am- monia nitrogen content in the samplers was determined by FIAstar 5000, measurable contents of $0.005-1.0 \mathrm{mg} \mathrm{L}^{-1}$ [29]. Total fluxes were then integrated, considering the vertical areas representing by the sampler positions. The net flux was calculated as total outgoing flux leaving the ammonia source area less total incoming background flux. This sampler construction permits separate measurement of fluxes from both the ammonia source area and the background [27].

\section{RESULTS}

\subsection{Nitrogen Field Balance}

The hut farm in year 2 had the largest total amounts of $\mathrm{N}$ excreted in the pen, corresponding to $161 \mathrm{~kg} \mathrm{~N} \mathrm{pig}^{-1}$ (Table 4). Overall, the sub-areas preferred for excretion in all three pens had 10- to over 100-fold higher amounts of $\mathrm{N}$ excreted per square metre than the sub-areas not preferred for excretion (Table 4).

The calculated mean amounts of $\mathrm{N}$ excreted per week for 35 pigs in the pen where cumulative ammonia losses were measured at the hut farm showed that the majority of the $\mathrm{N}$, corresponding to $103 \mathrm{~kg} \mathrm{~N}$ or $64 \%$ of the total $161 \mathrm{~kg} \mathrm{~N}$ excreted, was excreted during the latter half of the fattening period (11 July-17 September) Fig. (4). When the number of pigs per pen started to decrease on 17 September (Table 3), 


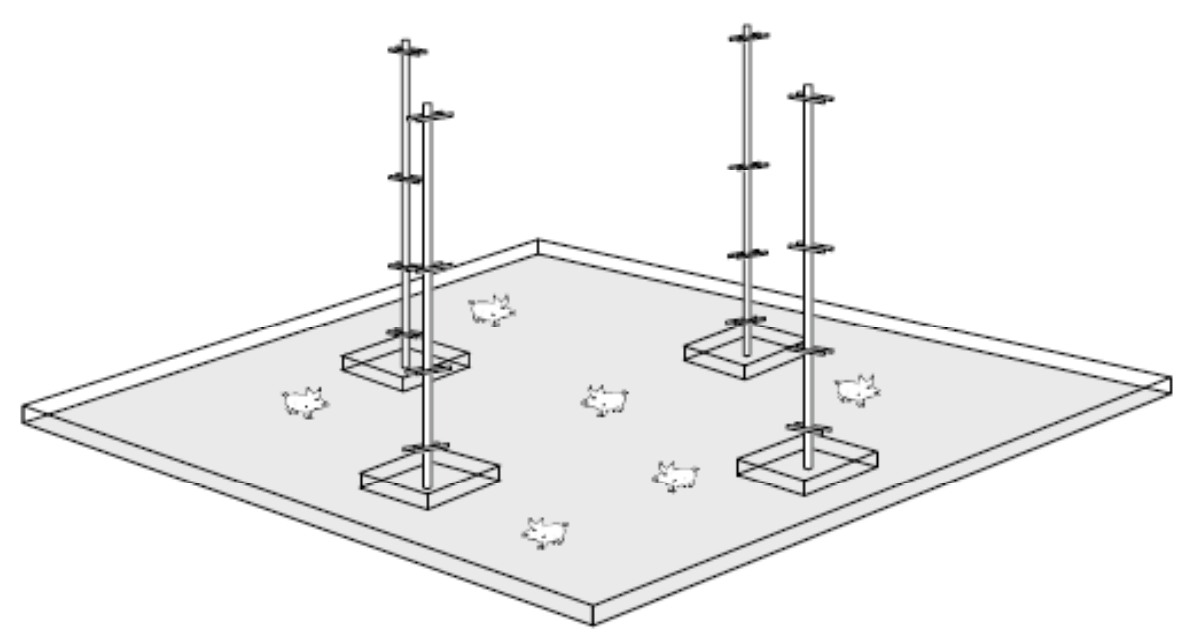

Fig. (3). Sampling arrangement for ammonia measurement with passive flux samplers. The horizontal outgoing and incoming fluxes of ammonia through the samplers are representative of vertical sub-areas surrounding the excreted faeces and urine.

the amounts of $\mathrm{N}$ excreted also decreased to the end of the period.

Table 4. Nitrogen Field Balance of Total Amounts of N Excreted in Pens and Amounts of $N$ Excreted in SubAreas Preferred (P) and not Preferred (NP) for Excretion within Pens at the hut Farm and the Barn Farm

\begin{tabular}{|c|c|c|c|}
\hline \multirow{2}{*}{$\begin{array}{l}\text { System } \\
\text { Year }\end{array}$} & \multicolumn{2}{|c|}{$\underline{\text { Hut farm }}$} & \multirow{2}{*}{$\frac{\text { Barn farm }}{2}$} \\
\hline & & 2 & \\
\hline${ }^{3}$ Total $\mathrm{N}$ excreted in the pen, $\mathrm{kg}$ & 83 & 161 & 74 \\
\hline N excreted in the pen, $\mathrm{kg} \mathrm{pig}^{-1}$ & 2.4 & 4.6 & 2.3 \\
\hline N excreted in $\mathrm{P}$ sub-areas, $\mathrm{g} \mathrm{m}^{-2}$ & 434 & 462 & 309 \\
\hline $\mathrm{N}$ excreted in NP sub-areas, $\mathrm{g} \mathrm{m}^{-2}$ & 1 & 3 & 17 \\
\hline
\end{tabular}

${ }^{a}$ In the pen at the barn farm, $\mathrm{N}$ amounts excreted indoors in the litter bed were excluded.

\subsection{Spatial Variation in Ammonia Losses}

At the end of the fattening period, ammonia losses from the sub-areas preferred for excretion were more than three times higher than those from the sub-areas not preferred for excretion within each pen (Table 5). The highest ammonia losses (1.843 $\mathrm{g} \mathrm{ha}^{-1} \mathrm{hr}^{-1}$ ) occurred from the sub-area preferred for excretion at the barn farm. Overall, there was no precipitation during any of the measuring periods.

\subsection{Cumulative Ammonia Losses During a Fattening Period}

At the hut farm in year 2, the difference in ammonia losses between sub-areas varied between measuring periods, from 1.5 times higher up to 100 times higher from the subareas preferred for excretion compared with sub-areas not preferred for excretion (Table 6). The exception was the first measuring period in June, where ammonia losses were close to zero in sub-areas both preferred and not preferred for excretion.

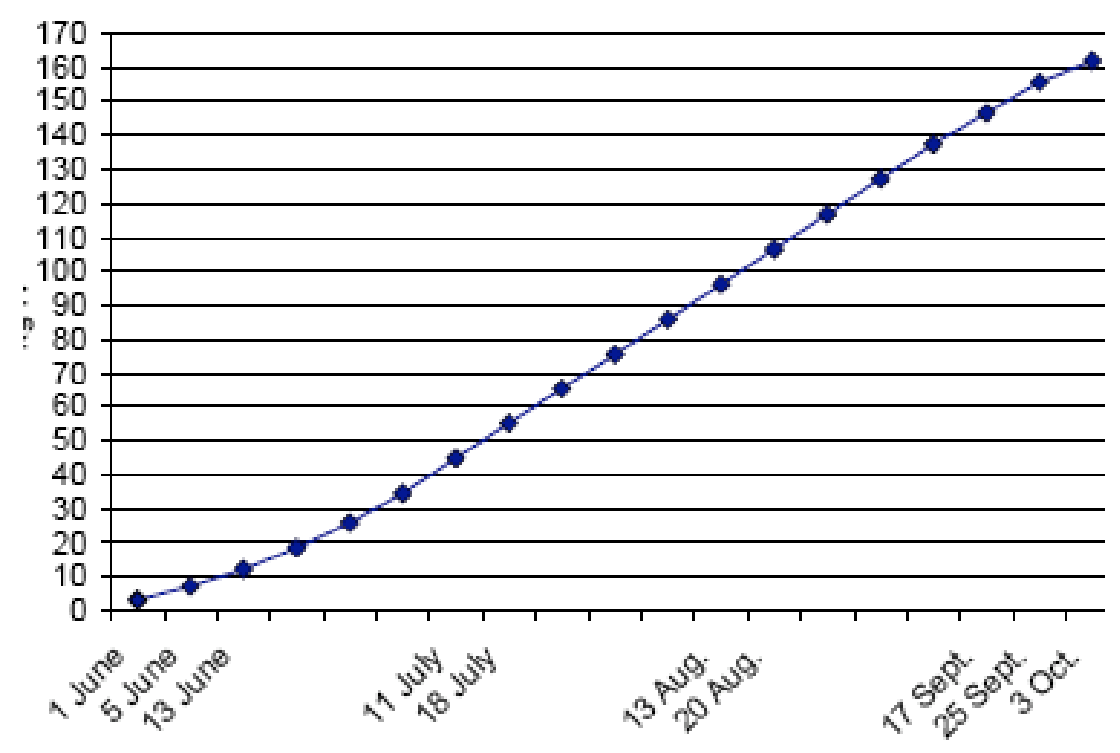

Fig. (4). The calculated mean cumulative amount $(\mathrm{kg})$ of $\mathrm{N}$ excreted during the period 1 June-3 October by 35 pigs at the hut farm in year 2 . 
Table 5. Total $\mathbf{N}$ Losses from Each Sub-Area within Pens at the hut Farm (HF) and the Barn Farm (BF) at the End of the Fattening Period, Determined by the Equilibrium Concentration Method

\begin{tabular}{|c|c|c|c|}
\hline \multirow{2}{*}{$\begin{array}{l}\text { Farm } \\
\& \text { year }\end{array}$} & \multicolumn{3}{|c|}{$\underline{\mathrm{N}}$ losses as $\mathrm{NH}_{3}, \mathrm{~g} \mathrm{ha}^{-1} \mathrm{hr}^{-1}$} \\
\hline & ${ }^{a p}$ & ${ }^{2} \mathrm{NP}$ & ${ }^{2} \mathrm{NP}$ \\
\hline HF 1 & 1.233 & 0.332 & - \\
\hline HF 2 & 0.056 & 0.001 & - \\
\hline BF 2 & 1.843 & 0.106 & 0.011 \\
\hline
\end{tabular}

${ }^{a}$ Sub-areas preferred (P) and not preferred (NP) for excretion.

Table 6. Average Ammonia $\left(\mathrm{NH}_{3}\right)$ Losses for Each Measuring Period from Sub-Areas Preferred (P) and not Preferred (NP) for Excretion at the hut Farm Pen in Year 2. Ferm Tubes were Used for Measuring Micrometeorological Mass Balance

\begin{tabular}{lccccc}
\hline \multicolumn{5}{c}{ Starting date of each measuring period. g NH $\mathrm{ha}^{-1} \mathrm{hr}^{-1}$} \\
Sub-area & 5 June & 11 July & 13 Aug. & 17 Sept. & 25 Sept. \\
\hline P & -0.063 & 0.119 & 0.536 & 0.337 & 0.324 \\
NP & 0.005 & -0.001 & -0.042 & 0.147 & 0.207 \\
\hline
\end{tabular}

Around $25 \mathrm{~kg}$ of the total ammonia losses of about $28 \mathrm{~kg}$ $\mathrm{NH}_{3}$ during the fattening period came from the sub-area preferred for excretion, Fig. (5). The majority of the ammonia losses from the sub-area preferred for excretion occurred during the measuring period 11 July to 25 September. The majority of the ammonia losses from the sub-area not preferred for excretion occurred during the last measuring period, between 17 September and 3 October, Fig. (5). During the previous measuring period (11 July-17 September), the results indicated deposition of ammonia on the sub-area not preferred for excretion, Table 6 and Fig. (5).
The mean gross $\mathrm{NH}_{3}$ losses from fattening pigs reared outdoors during the whole fattening period amounted to about $59 \mathrm{~kg} \mathrm{~N} \mathrm{ha}^{-1}$, which represented about $14 \%$ of total $\mathrm{N}$ excreted ha ${ }^{-1}$, Tables 4 and 7 . The proportion of $\mathrm{NH}_{3}$ losses compared with excreted $\mathrm{N}$ amounts was about $23 \%$ from the sub-areas not preferred for excretion and about $1 \%$ from the sub-areas preferred for excretion, Table 7.

Table 7. Nitrogen Losses from Sub-Areas Preferred $(P)$ and not Preferred (NP) for Excretion at the hut Farm in Year 2, Representing the whole Fattening Period

\begin{tabular}{|c|c|c|c|}
\hline \multicolumn{4}{|c|}{ Nitrogen losses } \\
\hline Sub & $\mathrm{Nha}^{-1}$ & $\mathrm{~kg} \mathrm{~N}_{\text {pig }}{ }^{-1}$ & $\%$ of excreted $\mathrm{Nha}^{-1}$ \\
\hline$P$ & 52.4 & 0.59 & 1.2 \\
\hline NP & 6.9 & 0.07 & 23.0 \\
\hline
\end{tabular}

\section{DISCUSSION}

\subsection{Nitrogen Field Balance}

Although the pig density and amounts of $\mathrm{N}$ fed per pig varied between pig groups, the nitrogen field balance showed a large net input of $\mathrm{N}$ to all three pens outdoors, with most of the $\mathrm{N}$ input allocated to the sub-areas where the pigs preferred to excrete, Table 4. The larger $\mathrm{N}$ loads excreted on preferred sub-areas indicated a higher risk of ammonia losses from these sub-areas than from not preferred sub-areas. The barn farm had highest pig density in the pen, but $19 \%$ of total excreted $\mathrm{N}$ was excreted indoors in the deep litter bed, which resulted in smaller amounts of $\mathrm{N}$ being excreted in the pen. However, in a parallel study the proportion of excretions indoors in the deep litter bed varied between pig groups fattened during the same time period at the barn farm [22]. Different excretion behaviour between pig groups can thus influence the $\mathrm{N}$ amounts excreted outdoors and the risk of ammonia losses from outdoor pens.

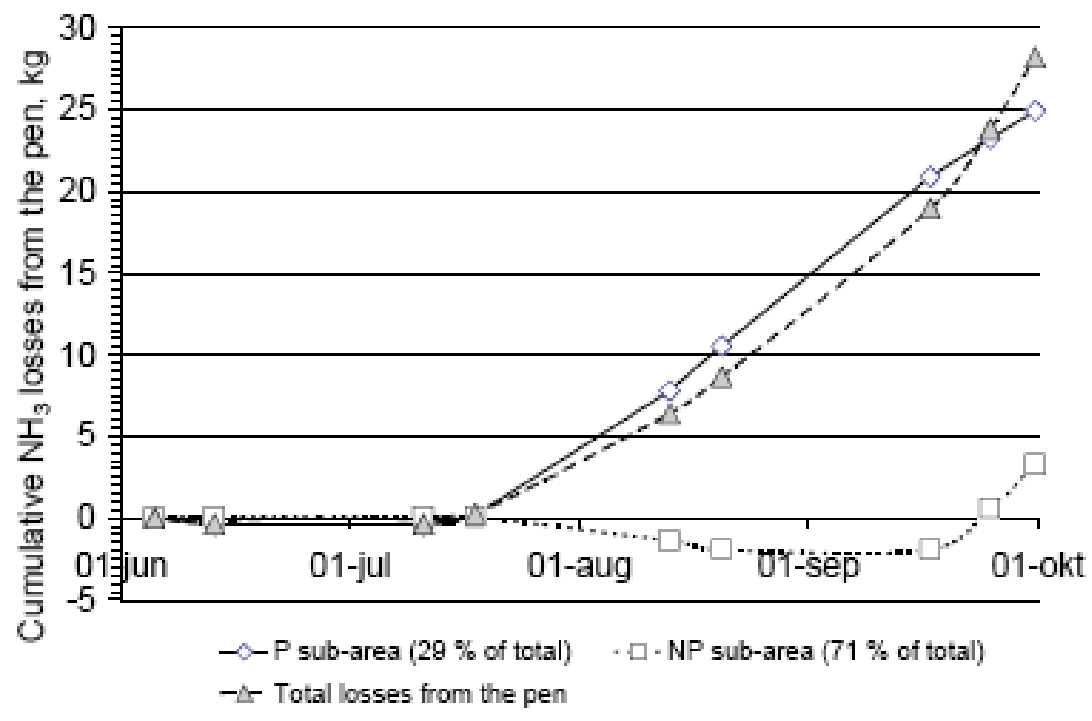

Fig. (5). Cumulative ammonia $\left(\mathrm{NH}_{3}\right)$ losses $(\mathrm{kg})$ between 1 June and 3 October from a pen $\left(3899 \mathrm{~m}^{2}\right)$ at the hut farm with 35 fattening pigs in year 2 . 
At the hut farm in year 2, 63\% of total $\mathrm{N}$ amounts excreted from the pig group studied were excreted in the latter half of the fattening period, indicating a higher risk of ammonia losses from pigs consuming the largest amounts of feed, Fig. (4). In a Danish study [9] it was found that in relation to other variables such as air temperature, incident solar radiation and precipitation, a change in the amount of feed given to the pigs gave the greatest change in ammonia losses.

\subsection{Spatial Variation in Ammonia Losses within Pens}

Although differences arose in climate and soil conditions between pens in this study, at the end of the fattening period within the same pen there was a clear tendency for the ammonia losses to be higher from the sub-areas preferred for excretion (0.056-1.843 $\mathrm{g} \mathrm{NH}_{3} \mathrm{ha}^{-1} \mathrm{hr}^{-1}$ ), compared with ammonia losses from sub-areas not preferred for excretion (0.001-0.332 $\mathrm{g} \mathrm{NH}_{3} \mathrm{ha}^{-1} \mathrm{hr}^{-1}$ ). A Swedish study [30] also reported higher momentary ammonia losses from outdoor areas where the pigs preferred to excrete (106 $\left.\mathrm{g} \mathrm{NH}_{3} \mathrm{ha}^{-1} \mathrm{hr}^{-1}\right)$ compared with areas not preferred (24 and $11 \mathrm{~g} \mathrm{NH}_{3} \mathrm{ha}^{-1}$ hour $\left.^{-1}\right)$. Danish studies $[9,10]$ found that ammonia losses close to the feeders were at least 10-fold higher than ammonia losses at 30-40 $\mathrm{m}$ distance away in pens with lactating sows. At that distance there were also surfaces with no ammonia losses. Furthermore, at the hut farm in year 2, ammonia losses from the sub-areas not preferred for excretion were close to zero. However, in year 1 the sub-areas not preferred for excretion had 300-fold higher ammonia losses than the corresponding sub-areas in year 2, indicating that of the measurable ammonia losses from sub-areas not preferred for excretion varied more than those from sub-areas preferred for excretion. The reason can be that even if the grazing area was not a preferable area for excretion, the pigs defecated and urinated occasionally on their way to and from the grazing area [15]. This means that the timing and location of measurable ammonia losses from the grazing area were more random than from sub-areas preferred for excretion, which had a continuous deposition of faeces and urine, resulting in measurable ammonia losses being more predictable from the latter sub-areas. The difference in pen design between the hut farm and barn farm may have had some influence on excretion behaviour and ammonia losses. The sub-area preferred for excretion at the barn farm had the highest ammonia losses per hectare and hour, Table 5, and was much smaller than that at the hut farm. In a parallel study [15], the average number of defecations and urinations on the subarea preferred for excretion at the barn farm was found to be significantly higher than at the hut farm. This higher frequency of defecation and urination indicates a risk of larger ammonia losses. In this study, the majority of ammonia losses probably came from excreted urine, from which most of the ammonia is released within 24 hours of excretion [31].

At higher air and soil temperatures higher ammonia losses can be expected [14]. In this study, the highest ammonia losses $\left(1.843 \mathrm{~g} \mathrm{NH}_{3} \mathrm{ha}^{-1} \mathrm{hr}^{-1}\right)$ were measured at the barn farm in the sub-area preferred for excretion. This sub-area had the highest mean air and soil temperatures during the two measuring periods, which can explain the high ammonia losses. However, the influence of air and soil temperature on ammonia losses was less clear on sub-areas preferred for excretion at the hut farm.

\subsection{Amounts of $\mathbf{N}$ Excreted and Cumulative Ammonia Losses During the Fattening Period}

At the hut farm in year 2, the majority of cumulative ammonia losses were emitted during the latter half of the fattening period from the sub-area preferred for excretion, Fig. (5). The weather conditions during this period were warm and dry in July, favouring ammonia losses, but thereafter they were less favourable as the air temperature sank and there was rain during measurement periods (Table 3 ). However, during the latter half of the fattening period, when pigs excreted maximum amounts of $\mathrm{N}$ (Fig. 4), this seemed to be a variable that influenced ammonia losses more than climate variables. Similar conclusions were reached in Danish studies $[9,10]$ where ammonia losses increased significantly with the amounts of feed, and thus $\mathrm{N}$, given to the pigs. In the present study the ammonia losses were close to zero at the beginning of the fattening period although mean air temperature was $16.3{ }^{\circ} \mathrm{C}$ during the measuring period. It seemed that in the beginning of the fattening period the amounts of $\mathrm{N}$ excreted in the pen were too small to be a variable that influenced ammonia losses, Fig. (4) and Fig. (5). During the period with the largest amounts of feed supply and $\mathrm{N}$ amounts excreted, the results indicated ammonia deposition on the sub-area not preferred for excretion from nearby point sources such as the sub-area preferred for excretion, Fig. (5). Re-deposition of ammonia can also occur. For example, in a study in the UK [32], 20-60\% of the ammonia emitted from urine patches on grassland was deposited within $2 \mathrm{~m}$ of the source.

Although ammonia losses per pig were lower from the sub-area not preferred for excretion at the hut farm in year 2, the proportion of ammonia losses compared with excreted $\mathrm{N}$ amounts was about $23 \%$ from the sub-area not preferred (grazing area) for excretion and about $1 \%$ from the sub-area preferred for excretion (between the hut and the feeding troughs) (Table 7). It was surprising that a higher proportion of $\mathrm{N}$ excreted on the grazing area was lost as ammonia, as the average number of defecations and urinations was lowest in this area. One explanation could be that a larger proportion of excreted $\mathrm{N}$ probably had soil contact in the sub-area preferred for excretion, as the pigs preferred to root around the water facilities [15]. Contact between manure and soil decreases the risk of ammonia losses [33].

\subsection{Ammonia Losses in Outdoor Pig Production}

In this study, the estimated total cumulative ammonia losses from an average fattening pig reared outdoors during the grazing period was $0.66 \mathrm{~kg} \mathrm{~N}$ (Table 7), representing $14 \%$ of excreted N. As there are few studies on ammonia losses from outdoor pigs, this result can only be compared with the few data that are available. A Danish study [9] calculated gross ammonia emissions over a year and found lower values, corresponding to $0.34 \mathrm{~kg} \mathrm{~N}$ fattening pig $^{-1}$. The animal density was higher than in this study, 24 farrowing sows $\mathrm{ha}^{-1}$ corresponding to 114 fattening pigs ha ${ }^{-1}$. Other studies $[9,10]$ concluded that manure excreted outdoors from pig production did not seem to contribute to reduced ammonia losses from livestock production compared with manure handling in indoor pig production. However, for a relevant comparison the total ammonia losses, including storage and spreading the manure from indoor systems, should be taken 
into account. Calculations of best management practice for slurry in Swedish fattening pig production showed that an indoor fattening pig had gross ammonia losses of $0.81 \mathrm{~kg} \mathrm{~N}$ [34]. However, in a survey of how Swedish farmers handled manure in 2004/2005, the mean ammonia losses from a fattening pig were $3.0 \mathrm{~kg} \mathrm{~N} \mathrm{[2].} \mathrm{This} \mathrm{indicates} \mathrm{that} \mathrm{ammonia}$ losses can vary considerably between optimal and real conditions in indoor fattening pig production. However, measurements of ammonia losses outdoors are more influenced than indoor systems by continuously changing site-specific conditions such as temperature, precipitation, soil infiltration capacity, pig activities and constant addition of excreted faeces and urine. These further variables render it difficult to obtain representative measurements of ammonia losses from outdoor pig production.

\section{CONCLUSION}

At the end of the fattening period the ammonia losses were higher from the sub-areas preferred for excretion compared with sub-areas not preferred for excretion in all pens, although there were differences in climate and soil conditions during ammonia measurement. The sub-area preferred for excretion at the barn farm had the largest ammonia losses and a larger number of defecations and urinations than the corresponding sub-areas at the hut farm. This may be one variable that increases ammonia losses from the preferred sub-areas. There was a tendency for measurable ammonia losses to vary more from sub-areas not preferred for defecation than from preferred sub-areas. The reason could be that the timing and location of measurable ammonia losses from the sub-areas not preferred for excretion were more random.

The influence of pigs on ammonia losses appeared to be most pronounced in the latter half of the fattening period, when they excreted maximum amounts of N. During that period the majority of total cumulative ammonia losses originated from the sub-area preferred for excretion. In the first half of the fattening period, excretion of $\mathrm{N}$ by pigs did not seem to influence ammonia losses.

\section{CONFLICT OF INTEREST}

None declared.

\section{ACKNOWLEDGEMENTS}

This study was financed by the Swedish Research Council for Environment, Agricultural Sciences and Spatial Planning (FORMAS).

\section{REFERENCES}

[1] Steinfeld H, Gerber P, Wassenaar T, Castel V, Rosales M, de Haan S. Livestock's long shadow - environmental issues and options, FAO, Rome, ISBN 978-92-5-105571-7 2006; pp. 79-122.

[2] SCB. Utsläpp av ammoniak till luft i Sverige 2005. MI 37 SM 0701, Statistics Sweden, Stockholm 2007; pp. 24 (English summary).

[3] SCB. Jordbruksstatistisk årsbok. Statistics Sweden, Örebro 2007; pp. 382. (English summary)

[4] Deering J, Shepherd CM. Outdoor pig production in England. Pig News Inform 1985; 6: 445-7.

[5] Andresen N. The Foraging Pig - Resource Utilisation, Interaction, Performance and Behaviour of Pigs in Cropping Systems. Uppsala, Doctoral Thesis 227: Swedish University of Agricultural Sciences, 2000.
[6] KRAV [web site on the Internet]. The standards of the KRAV label [cited 2007 Aug 6]. Available from: http://www.krav.se

[7] KRAV [web site on the Internet]. Årsredovisning 2006 [cited 2007 Aug 29]. Available from: http://arkiv.krav.se/arkiv/arsredovisning/ Arsredovisning2006.pdf

[8] Williams JR, Chambers BJ, Hartley AR, Ellis S, Guise HJ. Nitrogen losses from outdoor pig farming systems. Soil Use Manage 2000; 16: 237-43.

[9] Sommer SG, Søgaard HT, Møller HB, Morsing S. Ammonia volatilization from sows on grassland. Atmos Environ 2001; 35: 202332.

[10] Eriksen J, Petersen S, Sommer S. The fate of nitrogen in outdoor pig production. Agronomie 2002; 22: 863-7.

[11] Edwards SA, Jamieson W, Riddoch I, Watson CA. Effect of nose ringing and dietary modification in outdoor pig production on temporal changes in soil nitrogen status. Proc Br Soc Anim Sci 1998; p. 42.

[12] Zihlmann U, Weisskopf P, Menzi H, Ingold U. Bodenbelastung durch Freilandsschweine. Agrarforschung 1997; 4: 459-62.

[13] Watson CA, Anssems E, Kuhne B, Scholzel Y, Edwards SA. Assessing the nitrogen pollution risk from outdoor pig systems. In: Petchey A, Dárcy B, Frost A, Eds. Diffuse Pollution and Agriculture II. SEC. Aberdeen: Scotland, UK 1998; pp. 230-5.

[14] Svensson L. Ammonia volatilization following application of livestock manure to arable land. J Agric Eng Res 1994; 58(4): 241-60.

[15] Benfalk C, Lindgren K, Lindahl C, Rundgren M. Mobile and stationary systems for organic pigs - animal behaviour in outdoor pens. In: Köpke U, Niggli U, Neuhoff D, Cornish P, Lockeretz W, Willer H, Eds. Res Sustain Syst 2005; pp. 242-5.

[16] Soil Survey Staff. Keys to Soil Taxonomy, 7th ed. United States Department of Agriculture, Washington DC 1996.

[17] Salomon E, Åkerhielm H, Lindahl C, Lindgren K. Outdoor pig fattening at two Swedish organic farms - Spatial and temporal load of nutrients and potential environmental impact. Agric Ecosyst Environ 2007 ; 121 : 407-18

[18] SMHI [web site on the Internet]. Swedish Meteorological and Hydrological Institute [cited 2007 Aug 4]. Available from: http://www.smhi.se

[19] Alexandersson H, Eggertsson KC. Temperature and precipitation in Sweden 1961-1990. The Swedish Meteorological and Hydrological Institute (SMHI), Norrköping 2001; 99(2): p. 71.

[20] Damgaard PH. Pigs. In: Damgaard Poulsen H, Friis Kristensen V, Eds. Standard Values for Farm Manure. DIAS, Ministry of Food, Agriculture and Fisheries, Denmark 1998; 7(Appendix 3): pp. 8996.

[21] Fernández JA. Deposition and content of N, P and K in slaughter pigs. In: Damgaard PH, Friis KV, Eds. Standard Values for Farm Manure. DIAS, Ministry of Food, Agriculture and Fisheries, Denmark 1998; 7(Appendix 4): pp. 97-107.

[22] Salomon E, Benfalk C, Lindahl C, Lindgren K. Mobile and stationary systems for pigs - nutrient excretion, distribution on outdoor areas and environmental impact. In: Köpke U, Niggli U, Neuhoff D, Cornish P, Lockeretz W, Willer H, Eds. Res Sustain Syst 2005; 254-7.

[23] Svensson L. A new dynamic chamber technique for measuring ammonia emissions from land-spread manure and fertilizers. Acta Agric Scand Sect B, Soil Plant Sci 1993; 44(1): 33-46.

[24] Saarijärvi K, Mattila PK, Virkajärvi P. Ammonia volatilization from artificial dung and urine patches measured by the equilibrium concentration technique (JTI method). Atmos Environ 2006; 40: 5137-45.

[25] Malgeryd J. Technical measures to reduce ammonia losses after spreading of animal manure. Nutrient Cycling Agroecosyst 1998; 51:51-7.

[26] Svensson L, Ferm M. Mass transfer coefficient and equilibrium concentration as key factors in a new approach to estimate ammonia emission from livestock manure. J Agric Eng Res 1993; 56(1): $1-11$.

[27] Schjørring JK, Sommer SG, Ferm M. A simple passive sampler for measuring ammonia emission in the field. Water Air Soil Pollut 1992; 62: 13-24.

[28] Rodhe L, Karlsson S. Ammonia emissions from broiler manure influence of storage and spreading method. Biosyst Eng 2002; 82(4): 455-62.

[29] ISO 11732. Determination of ammonium in water by FIAstar 5000. 
[30] Gustafson GM, Svensson L. Ammonia emissions from pigs on deep litter beds and in a strip grazing system. J Sustain Agric 2003; 23(2): 41-51.

[31] Petersen SO, Sommer SG, Aaes O, Søegaard K. Ammonia losses from urine and dung of grazing Cattle: effect of $\mathrm{N}$ intake. Atmos Environ 1998; 32(3): 295-300.
[32] Ross CA, Jarvis SC. Measurement of emission and deposition patterns of ammonia from urine in grass swards. Atmos Environ 2001; 35: 867-75.

[33] Rodhe L, Richert Stintzing A, Steineck S. Ammonia emissions after application of human urine to a clay soil for barley growth. Nutrient Cycling Agroecosyst 2004; 68: 191-8.

[34] SJV. STANK Version 4.22, Computer Calculation Program. The National Board of Agriculture, Jönköping, Sweden 2003.

(C) Salomon et al.; Licensee Bentham Open.

This is an open access article licensed under the terms of the Creative Commons Attribution Non-Commercial License (http://creativecommons.org/licenses/by-nc/3.0/) which permits unrestricted, non-commercial use, distribution and reproduction in any medium, provided the work is properly cited. 